\title{
Torque Teno Mini Virus Infection in Chronic Cervicitis and Cervical Tumors in Isfahan, Iran
}

\author{
Leila Changani $^{a} \quad$ Majid Bouzari $^{\mathrm{a}} \quad$ Ardeshir Talebi $^{\mathrm{b}}$ \\ a Department of Biology, Faculty of Science, University of Isfahan, and ${ }^{\mathrm{b}}$ Pathology Laboratory, \\ Al-Zahra University Hospital, Faculty of Medicine, Isfahan University of Medical Sciences, Isfahan, Iran
}

\section{Key Words}

Torque teno mini virus - Cervical cancer · Adenocarcinoma . Squamous cell carcinoma - Cervical intraepithelial neoplasia $\cdot$ Cervicitis $\cdot$ Nested polymerase chain reaction

\begin{abstract}
Objectives: Torque teno mini virus (TTMV) is classified as the Betatorquevirus genus of Anelloviridae. Little is known about the prevalence of TTMV in humans. Worldwide, cervical cancer is the second most common cancer affecting women. This study aimed to estimate the TTMV infection frequency in cervicitis cases and cervical tumors including intraepithelial neoplasia (CIN), squamous cell carcinoma (SCC) and adenocarcinoma, and the possible role of this virus in the etiology of them in an Isfahan population. Methods: 79 cervicitis cases and 42 tumors were collected from histopathological files of Al-Zahra Hospital in Isfahan, Iran. DNA was extracted and subjected to nested polymerase chain reaction. Results: Totally $62 \%$ of the tested samples were positive for TTMV. It was positive in $52.4 \%$ of adenocarcinoma, $68.4 \%$ of CIN and $100 \%$ SCC cases. In cervicitis, $48 \%$ of the cases were positive. In the phylogenetic construct two of the cervical tumor isolates and two of the cervicitis isolates were placed in the same cluster with already
\end{abstract}

reported isolates from Japan (EF538880 and AB041962). Also, three of the cervical tumors isolated (JQ734980, JQ734981 and JQ734982) were placed in another cluster. Conclusion: The presence of the virus in cervical tissues suggests possible sexual transmission of the virus.

Copyright $\odot 2013$ S. Karger AG, Basel

In 2000, a virus smaller than torque teno virus (TTV) was discovered from the sera of Japanese blood donors by TTV primers (T935, T814) and designated as TTV-like mini virus (TLMV) [1-3]. The renaming of it was proposed by the International Committee on Taxonomy of Viruses (ICTV) as torque teno mini virus (TTMV) $[4,5]$. It is a nonenveloped, circular, negative sense singlestrand DNA $(2,860-2,910 \mathrm{nt})$ virus $<30 \mathrm{~nm}$ in diameter $[1,2,4,6-8]$ and is classified in nine species in the Betatorquevirus genus of the Anelloviridae family [9]. TTMV is transmissible by transfusion and is an intermediate between TTV and chicken anemia virus $[1,3,6]$.

After breast cancer, one of the main causes of death in women of reproductive age is cervical cancer and annually 500,000 cases of cervical cancer are diagnosed worldwide [10-13], of which $80 \%$ live in developing countries [11]. It is believed that human papillomavirus

\section{KARGER}

E-Mail karger@karger.com

www.karger.com/int (c) 2013 S. Karger AG, Basel

0300-5526/13/0564-0265\$38.00/0 
(HPV) plays a role in $95 \%$ of the cases. The etiology for $5 \%$ of the cases is unrelated to HPV $[12,14,15]$. Other sexually transmitted pathogens also increase the risk of cervical cancer in HPV-infected individuals [16, 17]. The cervical tumor prevalence varies from about 10 cases per 100,000 women per year in many industrialized countries to 40 per 100,000 in some developing countries [18].

The two main cervical cancers are adenocarcinoma and squamous cell carcinoma (SCC), of which SCC consists of $90-95 \%$ of all [10]. Adenocarcinoma is an epithelial gland cell tumor which progresses much faster than SCC [10]. The abnormal growth of precancerous cells in the cervix is called cervical intraepithelial neoplasia (CIN) [11].

Cervicitis is an inflammatory condition of the cervix which frequently is asymptomatic. It is considered to be associated with sexually transmissible pathogens with rates as high as $30-45 \%$ in populations affected with sexually transmitted infections [19]. While less than half of the cases are believed to be caused by Chlamydia and Neisseria gonorrhoeae, the etiology of the remainder which are referred to as nonchlamydial, nongonococal cervicitis or nonspecific cervicitis are unknown [19]. $M y$ coplasma genitalium, Mycoplasma hominis, Ureaplasma urealyticum, herpes simplex virus, cytomegalovirus, adenovirus and Trichomonas vaginalis are other pathogens which are variably implicated in the pathogenesis [19].

Preliminary reports on the prevalence of TTMV in the human population indicate high rates of infection in French (76-77\%) [20], Brazilian (72-77\%) $[8,21]$ and in Norwegian (48\%) [22] blood donors and also in French hemodialysis patients (95\%) [23]. TTMV DNA has been detected in amniotic fluid, cord blood and breast milk [8, 24]. TTMV genome has also been detected in cervical swabs of healthy women (61\%) [25], peripheral blood mononuclear cells, feces and saliva [6].

Considering this issue and the lack of information about the possible effects of TTMV in cervical tumors and cervicitis, the aim of this study was to determine the frequency of TTMV in cervical tumors and cervicitis cases and its possible correlation with them.

Seventy-nine cervicitis cases and 42 cervical tumors which were formalin-fixed and paraffin-embedded were collected from histopathological files of Al-Zahra Hospital in Isfahan, Iran. This study was approved by the local ethics committee. Of 42 tumors tested, 21, 19 and 2 cases were adenocarcinoma, CIN and SCC, respectively. Data on histopathological changes were collected by re-examination of standard hematoxylin- and eosin-stained sections. The tissues were stored in ambient conditions $\left(10-20^{\circ}\right)$ of the dry local climate. Before sectioning each sample, both the tissue blocks and the microtome were cleaned with absolute alcohol, and four $10-\mu \mathrm{m}$ thick sections from each block were then collected $[26,27]$.

Sections of tissue were subjected to xylene treatment $(1 \mathrm{ml})$ at $59^{\circ}$ for $15 \mathrm{~min}$ in 1.5-ml Eppendorf tubes and centrifuged at $11,300 \mathrm{~g}$ for $10 \mathrm{~min}$. The procedure was repeated three times, and the samples were then washed with $100 \%$ ethanol with three rounds of centrifugation at $9,660 \mathrm{~g}$ for $10 \mathrm{~min}$. Finally, the samples were air-dried for $30 \min [26,28]$.

The deparaffinized tissue sections were treated with $900 \mu \mathrm{l}$ of solution containing $50 \mu \mathrm{l}$ of $5 \mathrm{M} \mathrm{NaCl}, 200 \mu \mathrm{l}$ of $0.5 \mathrm{M}$ EDTA and $650 \mu \mathrm{l}$ of retrieval solution ( $1 \mathrm{M}$ Tris, $0.5 \mathrm{M}$ EDTA, $10 \%$ sodium dodecyl sulfate) and thermomixed at $450 \mathrm{rpm}$ for $15 \mathrm{~min}$ at $59^{\circ} .90 \mu \mathrm{l}$ of $0.5 \mathrm{mg} / \mathrm{ml}$ proteinase $\mathrm{K}$ was then added and thermomixed at $500 \mathrm{rpm}$ for $3 \mathrm{~h}$ at $59^{\circ}$. An equal volume of phenol/chloroform/isoamyl alcohol (25:24:1) (Merck, Germany) was added and the samples were then centrifuged at 4,290 $\mathrm{g}$ for $10 \mathrm{~min}$. The upper phase was collected and transferred to another microtube and 0.1 volume $3 \mathrm{M}$ sodium acetate was added, and the samples were vortexed for $1 \mathrm{~min}$. Then 2 volumes of cold $100 \%$ ethanol (Merck) were added and the sample was incubated at $-20^{\circ}$ overnight. The precipitated DNA was centrifuged at 9,660 $\mathrm{g}$ at $4^{\circ}$. The supernatant was discarded and the DNA precipitate was washed once with $75 \%$ ethanol. The pelleted DNA was dissolved in $50 \mu \mathrm{l}$ of distilled water or TE solution (Tris- $\mathrm{HCl}$ buffer ( $10 \mathrm{mM}, \mathrm{pH} 8.0)$ containing $1 \mathrm{mM}$ EDTA) after complete drying. Purity of extracted DNA was estimated as the ratio between spectrophotometric absorption at 260 and $280 \mathrm{~nm}\left(\mathrm{OD}_{260} / \mathrm{OD}_{280}\right)$ [28].

To confirm the quality of the extracted DNA, primers (D-141F: 5-ACCACGGAGCAAAGAACAGA-3) and (D141R: 5-GTCCTCCCGGCCTAGTCTTA-3) were used for detection of the housekeeping gene GJB2 of human chromosome 13, with a product size of $125 \mathrm{bp}$ [29]. Amplification of the GJB2 gene by polymerase chain reaction (PCR) was performed in 25 reaction volumes containing $2 \mu \mathrm{l}$ of the tissue extract, $1 \mathrm{U}$ of SmarTaq DNA polymerase per microliter (Cinnagen, Iran), $0.4 \mu \mathrm{M}$ of each primer, 240 mM of each dNTP, $20 \mathrm{mM}$ of Tris- $\mathrm{HCl}, 3 \mathrm{mM} \mathrm{MgCl}_{2}, 50$ $\mathrm{mM} \mathrm{KCl}$ and $20 \mathrm{~mm}$ of ammonium sulfate. Thermal cycling consisted of an initial denaturing step at $94^{\circ}$ for $5 \mathrm{~min}$, followed by 34 cycles of denaturation at $94^{\circ}$ for $60 \mathrm{~s}$, $60 \mathrm{~s}$ of annealing at $63.2^{\circ}, 1 \mathrm{~min}$ of elongation at $72^{\circ}$, and a post-elongation step of $10 \mathrm{~min}$ at $72^{\circ}$. 
The primer systems used for amplification of TTMV DNA (340 bp) included M1359/M1365 (sense: GTTTATSMCGCYAGACGGAG, PCR product: $433 \mathrm{bp}$; antisense: TYTGCGAAWAGGGCSTCTAA, PCR product: $433 \mathrm{bp}$ ) and M1360/M1366 (sense: GAAGGTGAGTGAAACACCG, PCR product: $340 \mathrm{bp}$; antisense: AGGGCSTCTAAWTCTCCKTC, PCR product: 340 bp) (K: G or T, M: A or C, S: G or C, W: A or T, Y: C or T) primer sets in nested PCR [3].

In the first round of PCR, $3 \mu \mathrm{l}$ of DNA, and in the second round, $1 \mu \mathrm{l}$ of the PCR product was used in a $25-\mu \mathrm{l}$ reaction mixture containing $1 \mathrm{U}$ SmarTaq polymerase (Cinnagen), $0.4 \mu \mathrm{M}$ each primer, $240 \mu \mathrm{M}$ each dNTP, $20 \mathrm{~mm}$ Tris- $\mathrm{HCl}, 3 \mathrm{mM} \mathrm{MgCl} 2,50 \mathrm{mM} \mathrm{KCl}$ and $20 \mathrm{~mm}$ ammonium sulfate. Thermal cycling conditions in the first round were as follows: initial denaturation at $94^{\circ}$ for $5 \mathrm{~min}$ followed by 30 cycles of denaturation at $94^{\circ}$ for $40 \mathrm{~s}$, annealing at $60^{\circ}$ for $40 \mathrm{~s}$, and an extension step at $72^{\circ}$ for $50 \mathrm{~s}$. The amplification program was followed by a final extension step at $72^{\circ}$ for $5 \mathrm{~min}$. The thermal cycling conditions in the second round of PCR were the same as in the first round. PCR products $(10 \mu \mathrm{l})$ from the second round were loaded onto a $1 \%$ agarose gel (Sigma) containing ethidium bromide and electrophoresed, and the DNA was viewed under UV light.

The PCR products (bands of about $340 \mathrm{bp}$ ) of seven randomly selected samples from cervicitis cases and tumor cases were subjected to agarose gel electrophoresis (1\%) and DNA was extracted according to guidelines of the DNA Gel Extraction Kit K0513(Fermentas, Germany). The DNAs were sequenced using an Applied Biosystem 3730 DNA Analyzer (Geneservice, UK). A nucleotide BLAST search of the determined sequences against the nucleotide sequence database (NCBI, National Center of Biotechnology Information) was performed.

A phylogenetic tree was constructed using the neighbor-joining method in MEGA4 (Molecular Evolutionary Genetics Analysis software version 4.1) [30] based on our sequenced amplicons with accession numbers of JQ734980, JQ734981, JQ734982, JQ734984 and JQ734986 of tumor cases and accession numbers of JQ734979 and JQ734985 of cervicitis cases against sequences obtained from GenBank. TTMV virus Isfahan isolates (GQ337059, GQ337060, GQ337061 and GQ337962), nine other TTMV isolates and two variants of TTV were obtained from GenBank database.

Fisher's exact test was used for statistical analysis using GraphPad Instat software version 3.05 (GraphPad, USA).

In the gel electrophoresis, expected 340-bp bands for TTMV were observed (fig. 1). In the phylogenetic con-

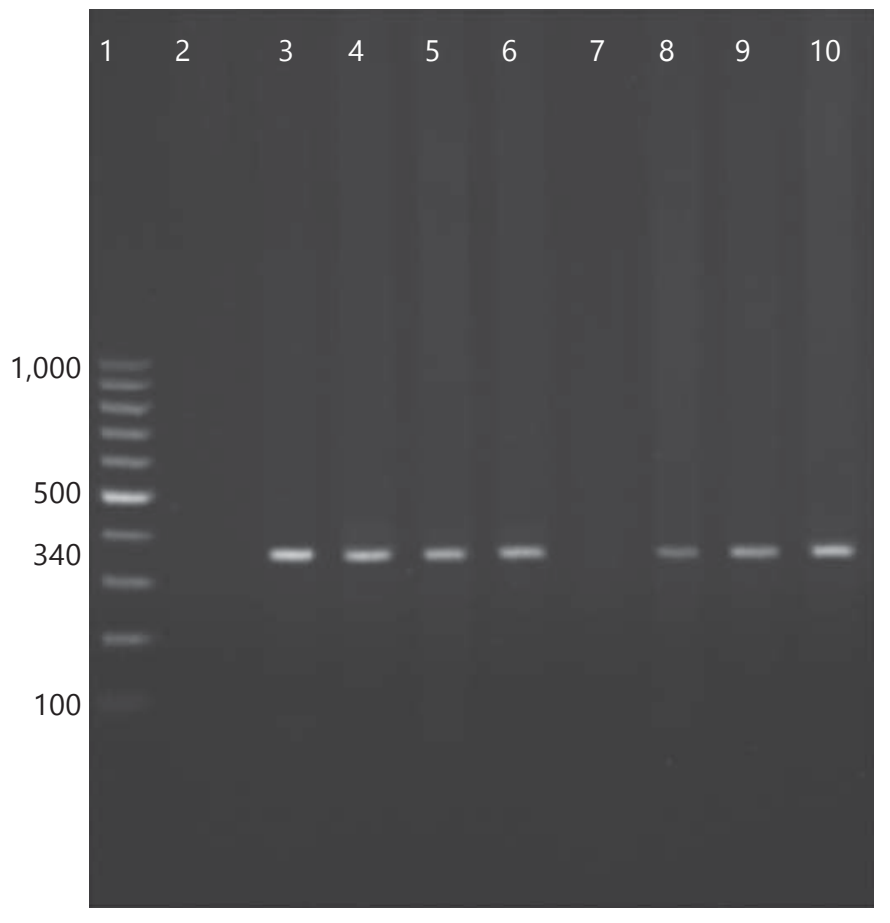

Fig. 1. Agarose gel electrophoresis of PCR products. Column 1: marker 100 bp DNA (Fermentas); column 2: negative control; column 3: positive control; columns 4-6, 8-10: TTMV-positive (340 bp); column 7: negative case.

struct, two of the cervical tumor isolates (JQ734984 and JQ734986) and two of the cervicitis isolates (JQ734979 and JQ734985) were placed in the same cluster with the already reported isolates from Japan (EF538880 and AB041962). Also, three of the cervical tumors isolated (JQ734980, JQ734981 and JQ734982) were placed in another cluster. This cluster also included the already reported isolates (GQ337060 and GQ337062) from sera of the same region. However, they were also far from isolates (GQ337059 and GQ337061) from the same region which were placed in another cluster (fig. 2).

The frequency of TTMV infection in different cervical tumors and cervicitis cases is shown in figures 3 and 4 . In total, $62 \%$ of the tested tumor samples were positive for TTMV. It was positive in 52.4, 68.4 and $100 \%$ of adenocarcinoma, CIN and SCC cases, respectively. In cervicitis samples, $48 \%$ of the tested samples were positive for TTMV.

The differences observed in the frequency of infection in different tumors were not significant $(\mathrm{p}>0.05)$. The difference in the frequency of infection in tumor cases and cervicitis cases was not significant $(p>0.05)$. 


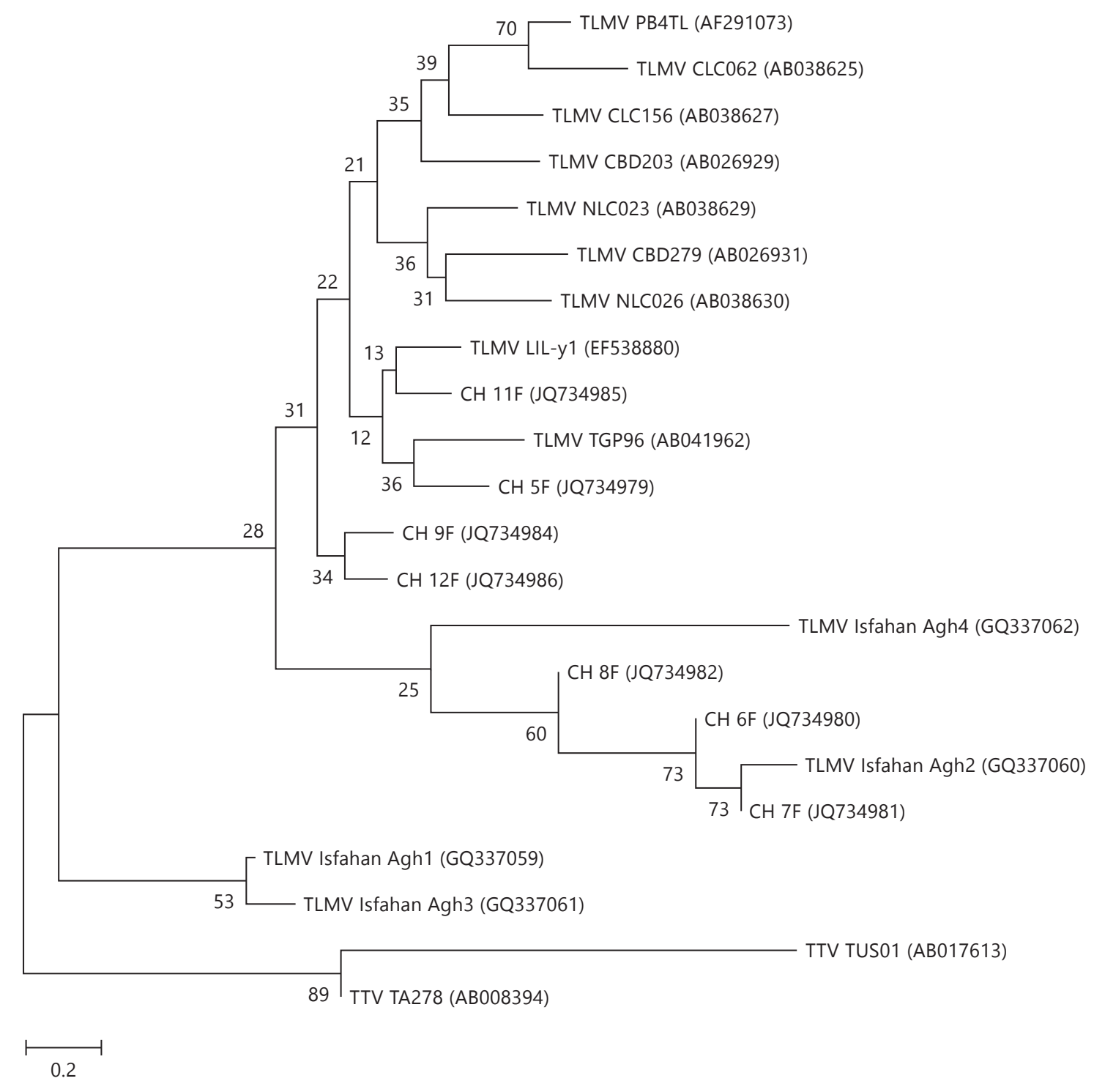

Fig. 2. Phylogenetic tree was constructed using the neighbor-joining method implemented in MEGA4.1 with 1,000 bootstrap replicates. Evolutionary distances were computed using the maximum composite likelihood model. The units are base substitutions per site. The numbers displayed at each branch separation are bootstrap values in percent.

The tumor and cervicitis cases were categorized into different age groups ( $\leq 20-39,40-59$, and $\geq 60$ ). The frequencies of the virus infection in different age groups are shown in table 1 . The difference among different age groups was not significant ( $\mathrm{p}>0.05$ ).

This study reports the presence of TTMV in cervical tumors and cervicitis cases for the first time. Preliminary reports on the prevalence of TTMV in the human popu- lation indicate high rates of infection in French (76$77 \%)$ [20], Brazilian (72-77\%) $[8,21]$ and Norwegian (48\%) [22] blood donors and also in French hemodialysis patients $(95 \%)$ [23].

The percentage of TTMV infection in cervical tumors in this study was $62 \%$, which was similar to $61 \%$ of infection of cervical swabs from healthy women tested in Italy [25]. Considering this, Fornai et al. [25] suggested 




Fig. 3. Frequency of TTMV infection in cervical tumors and cervicitis cases tested.

Table 1. Frequency of TTMV in different age groups of cervical tumors and cervicitis cases

\begin{tabular}{|c|c|c|c|c|c|c|}
\hline \multirow{2}{*}{$\begin{array}{l}\text { Age } \\
\text { groups }\end{array}$} & \multicolumn{3}{|c|}{ Tumors } & \multicolumn{3}{|c|}{ Cervicitis } \\
\hline & total & TTMV+ & positivity & total & TTMV+ & positivity \\
\hline$\leq 20-39$ & 7 & 4 & $58 \%$ & 26 & 9 & $34 \%$ \\
\hline $40-59$ & 21 & 13 & $62 \%$ & 33 & 19 & $57 \%$ \\
\hline$\geq 60$ & 13 & 9 & $69 \%$ & 8 & 6 & $75 \%$ \\
\hline
\end{tabular}

possible active replication of the virus in the genital tract, for example by lymphoid cells or exudation from plasma. The results obtained in this study show that the cervical tissues should be considered as the source of the virus in the genital tract. Matsubara et al. [24] detected TTMV in infant cord blood suggesting like other viruses, such as human immunodeficiency virus 1 , rubella virus, cytomegalovirus and parvoviruses which are transmitted through the intrauterine route, the mother-to-child transmission of TTMV could happen. The detection of TTMV in cervical tissues in this study is in favor of their suggestion.

The report by Fornai et al. [25] that detected TTMV in cervical swabs of healthy women suggests the possible

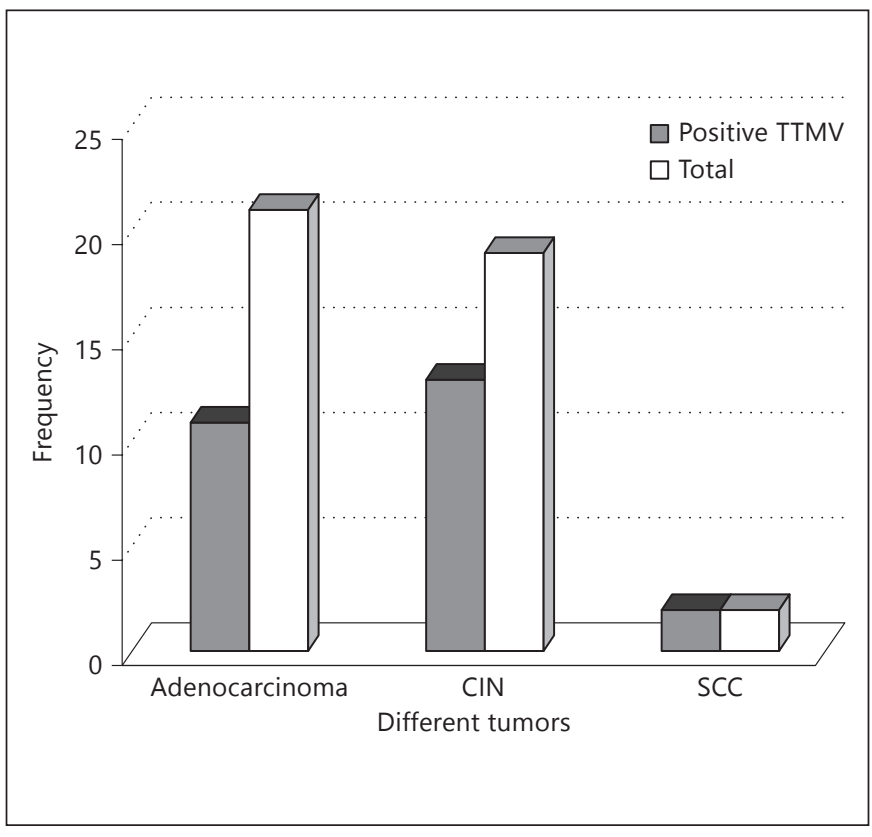

Fig. 4. Frequency of TTMV infection in different tumors tested.

sexual transmission of the virus that is in agreement with the results in this study. Ghazimorad and Bouzari [31] detected the virus in 17 out of 100 sera from healthy blood donors in Isfahan. The frequency of the virus detected in cervicitis and cervical tumors in this study in the same area is significantly higher than the sera $(\mathrm{p}<0.01)$. This may indicate that the changes in tissues induced by cervicitis and cervical tumors may have led to more replication and infection of the virus or the infection by the virus may have led to higher frequency of cervicitis or cervical tumors. Confirmation of these needs more sophisticated investigations.

Neil and Lampe [21] reported a high variability in one of the most conserved regions of the TTMV genomes detected in the sera of blood donors in Brazil. Takahashi et al. [1] also showed a high degree of genomic divergence for this virus. In the present study, a great diversity was also observed among the samples sequenced, with a homology rate from 70 to $85 \%$, which confirms the former reports. Phylogenetic analyses showed that some of the virus isolates are similar to those which were reported from other areas, especially Japan. On the other hand, some were similar to already reported isolates from the sera of the same region. This also confirms the variability of the virus.

It has been suggested that anelloviruses may be involved in various diseases such as pancreatic cancer, 
systemic lupus erythematosus, idiopathic inflammatory myopathies, or chromosomal translocation [4]. Although a statistical association between anellovirus infection (or viral load) and disease has been suggested, a causal relationship has not been proven [6]. In comparison of tumor and cervicitis cases, no significant differences were observed in the frequency of TTMV infection $(p>0.05)$. Moreover, the difference in the fre- quency of the virus in the different tumors tested was not significant $(p>0.05)$. Our results are in favor of the idea that TTMV as an anellovirus is not pathogenic.

\section{Acknowledgement}

This study was supported by a grant provided by the Department of Research and Postgraduate Studies of the University of Isfahan.

\section{References}

1 Takahashi K, Iwasa Y, Hijikata M, Mishiro S: Identification of a new human DNA virus (TTV-like mini virus, TLMV) intermediately related to TT virus and chicken anemia virus. Arch Virol 2000;145:979-993.

2 Biagini P: Human circoviruses. Vet Microbiol 2004;98:95-101.

3 Davidson I, Shulman LM: Unraveling the puzzle of human anellovirus infections by comparison with avian infections with the chicken anemia virus. Virus Res 2008;137:1-15.

4 Biagini P, de Micco P: Anellovirus; in Mahy BWJ, Van Regenmortel MHV (eds): Human and Medical Virology. San Diego, Academic Press Linacre House, 2010, pp 17-22.

5 Hino S: TTV, a new human virus with singlestranded circular DNA genome. Rev Med Virol 2002;12:151-158.

6 Biagini P, Gallian P, Attoui H, Touinssi M, Cantaloube J, de Micco P, de Lamballerie X: Genetic analysis of full-length genomes and subgenomic sequences of TT virus-like mini virus human isolates. J Gen Virol 2001;82:379-383.

7 Biagini P, Gallian P, Cantaloube J, Attoui H, de Micco P, de Lamballerie X: Distribution and genetic analysis of TTV and TTMV major phylogenetic groups in French blood donors. J Med Virol 2006;78:298-304.

8 Vasconcelos H, Cataldo M, Niel C: Mixed infections of adults and children with multiple TTV-like mini virus isolates. J Med Virol 2002;68:291-298.

9 ICTV virus taxonomy: 2009 release (9th report) available at: http://www.ictvonline.org/ virusTaxonomy.asp? version $=2009$

10 Spencer JV: Cervical Cancer. New York, Chelsea House Publishers, 2007, pp 10-15.

11 Cutts FT, Franceschi S, Goldie S, Castellsague X, de Sanjose S, Garnett G, Edmunds WG, Claeys P, Goldenthal KL, Harperi DM, Markowitz L: Human papillomavirus and HPV vaccines: a review. Bull World Health Organ 2007;85:719-726.
12 Wolfgang MJ, Mike F, Mirhashemi A: Epidemiology and biology of cervical cancer. Semin Surg Oncol 1999;16:203-211.

13 Zandi Z, Eghbali SS, Hamkar R, Ahmadi SH, Ramedani E, Deilami I, Aziz Nejad H, Farshadpour F, Rastian Z: Prevalence of various Human Papillomavirus (HPV) genotypes among women who subjected to routine Pap smear test in Bushehr city (south west of Iran) 2008-2009. Virol J 2010;7:65.

14 Zur Hausen H: Viruses in human cancers. Science 1991;254:1167-1173.

15 Lorincz AT, Lancaster WD, Temple CF: Cloning and characterization of the DNA of a new human papillomavirus from a woman with dysplasia of the uterine cervix. J Virol 1986;58: 225-229.

16 Salakova M, Nemecek V, Tachezy R: TTV and HPV co-infection in cervical smears of patients with cervical lesions. BMC Infect Dis 2009;9:118.

17 Munoz N, Castellsague X, de Gonzalez AB, Gissmann L: HPV in the etiology of human cancer. Vaccine 2006;3:S1/3-S3/10.

18 Parkin DM, Pisani P, Ferlay J: Estimates of the worldwide incidence of 25 major cancers in 1990. Int J Cancer 1999;80:827-841.

19 Lusk J, Konecny P: Cervicitis: a review. Curr Opin Infect Dis 2008;21:44-55.

20 Biagini P, Gallian P, de Micco P, de Lamballerie X: TT virus and TT virus-like mini-virus infection in French blood donors. Transfusion 2000;40:1542.

21 Niel C, Lampe E: High detection rates of TTV-like mini virus sequences in sera from Brazilian blood donors. J Med Virol 2001;65: 199-205.

22 Moen M, Huang L, Grinde B: Molecular epidemiology of TTV-like mini virus in Norway. Arch Virol 2002;147:181-185.
23 Gallian P, Biagini P, Attoui H, Cantaloube JF, Dussol B, Berland Y, de Micco P, de Lamballerie X: High genetic diversity revealed by the study of TLMV infection in French hemodialysis patients. J Med Virol 2002;67: 630-635.

24 Matsubara H, Michitaka K, Horiike N, Kihana T, Yano M, Mori T, Onji M: Existence of TT virus DNA and TTV-like mini virus DNA in infant cord blood: mother-to-neonatal transmission. Hepatol Res 2001;21: 280-287.

25 Fornai C, Maggi F, Vatteroni ML, Pistello M, Bendinelli M: High prevalence of TT virus (TTV) and TTV-like minivirus in cervical swabs. J Clin Microbiol 2001;39:2022-2024.

26 Salmanizadeh SH, Bouzari M, Talebi A: Detection of torque teno midi virus/small anellovirus (TTMDV/SAV) in chronic cervicitis and cervical tumors in Isfahan, Iran. Arch Virol 2012;157:291-295.

27 Bertelson BI, Kugarjh K, Skar R, Laerum OD: HPV subtypes in cervical cancer biopsies between 1930 and 2004: detection using general primer pair PCR and sequencing. Virchows Arch 2006;449:141-147.

28 Rivero ERC, Neves AC, Silva-Valenzuela MG, Sousa SOM, Nunes FD: Simple salting-out method for DNA extraction from formalinfixed, paraffin-embedded tissues. Pathol Res Pract 2006;202:523-529.

29 Alterescu G, Elder-Gava T, Brooks B: Preimplantation genetic diagnosis for nonsyndromic deafness by polar body and blastomere biopsy. J Assist Reprod Genet 2009;26:391-397.

30 Tamura K, Dudley J, Nei M, Kumar S: MEGA4: molecular evolutionary genetics analysis (MEGA) software version 4.0. Mol Biol Evol 2007;24:1596-1599.

31 Ghazimorad A, Bouzari M: Detection of TLMV in some blood donors in Isfahan. The Second Iranian Congress of Clinical Microbiology Abstract Book, Shiraz, Iran, 2008, pp 48. 